\title{
ロックウール断熱材を用いた木造断熱壁体の防耐火性能に関する研究 STUDY ON THE FIRE PROTECTING PERFORMANCE OF WOODEN EXTERNAL WALL WITH ROCKWOOL INSULATION
}

\author{
糸毛 治*, 鈴木大 隆**, 長谷見 雄二*** \\ Osamu ITOGE, Hirotaka SUZUKI and Yuji HASEMI
}

\begin{abstract}
Fire resistance tests are conducted on small-scale specimens of wooden wall with different positions and thicknesses of rockwool insulation in the wall. The tests have revealed significant influence that position and thickness of insulation in the wall give to the fire protecting performance of the wooden wall. It has been also clarified that putting insulation between wooden posts does not always make mechanical fire resistance improve, because positional relation between wooden post and insulated layer changed thermal distribution in the wall and damage wooden post given.
\end{abstract}

Keywords : Wooden wall, Rock-wool-insulation, Constructing method on Insulated wall, Insulation Thickness, Fire Protecting Performance 木造壁体，ロックウール断熱材，断熱工法，断熱材厚さ，防耐火性能

\section{1. はじめに}

地球環境問題への対応として、住宅における省エネルギー化が求 められる中、住宅の断熱化が急速に普及している。他国に比べ我が 国の住宅構法は多種多様であり、使用される断熱材や適用される断 熱工法により、建築外皮としての外壁の壁体仕様は多岐にわたる。 木造住宅の外壁の一般的な断熱工法には、軸間に断熱材を充てん する充てん断熱工法、木造躯体の屋外側に断熱材を張る外張断熱工 法、これらを組み合わせた付加断熱工法の 3 つがあり 1)、外壁とな る耐力壁の防耐火性能には、非損傷性、遮熱性、遮炎性の 3 つが求 められる。不燃性断熱材を用いた場合、断熱材が厚くなると、遮熱 性は有利になるが、非損傷性は木柱部の温度上昇に支配されるため、 木柱との位置関係によっては不利側になる可能性がある。この断熱 材と木柱の位置関係は断熱工法により異なるため、断熱工法ごとに 壁体の防耐火性能と木柱や断熱材の寸法等の関係は異なると予想さ れる。従って、断熱工法の防耐火性能に関寸る技術開発や性能評価 を見通し良く進めるためには、断熱工法ごとに、木造壁体の防耐火 性能が木柱や断熱材の寸法等とどう関係するのかを明らかにする必 要がある。

本研究では断熱材の寸法に着目し、小規模の試験体による試験(以 下、小型試験）にて、断熱工法ごとに防耐火性能と断熱材の厚さや 位置との関係について検討を行った。小型試験では、壁体の断面方 向の温度分布は実大壁を火災加熱した時と変わらないようにできる ため、遮熱性および遮炎性は再現できる。一方、非損傷性は、小型
試験では建材の変形量や脱落、木柱の座屈が再現できず、実大試験 により検討が必要であるが、小型試験であっても非損傷性を支配す る木材の炭化性状と柱の温度分布を把握すれば、非損傷性と壁の設 計内容の関係の見通しは得られると考えられる。

また各種発泡プラスチック断熱材などの有機系断熱材では、壁体 内で断熱材自体が燃焼してしまい、断熱工法による断熱材の設定位 置や厚みによる伝熱的な要因が把握できない。従って、本研究では 不燃材料であり最も高温時の熱変性が少ないロックウール断熱材を 用い、屋外加熱および屋内加熱それぞれの評価を行った。

\section{2. 試験方法}

\section{1 試験法}

試験は、幅 $800 \mathrm{~mm} \times$ 高さ $800 \mathrm{~mm}$ の小規模の試験体（加熱面：幅 $600 \mathrm{~mm} \times$ 高さ $600 \mathrm{~mm}$ ）を用いた。炉内温度を試験体表面から $100 \mathrm{~mm}$ の位置で $\phi 3.2 \mathrm{~mm}$ のシース熱電対 ( $\mathrm{K}$ 熱電対)により測定し、ISO834 加熱曲線に合うように加熱を行った。なお、試験体仕様は防火構造 を基本に設計した。防火構造では、屋外側のみ 30 分の火災加熱を 想定するが、この種の構成の壁は、被覆厚を操作して準耐火構造ま で用いられる可能性があるため、屋外加熱、屋内加熱の両方につい て非載荷で加熱時間を 60 分とした。

\section{2 試験体仕様}

試験体の仕様一覧を表 1 に示す。本研究では充てん断熱工法、外 張断熱工法、付加断熱工法の 3 つの断熱工法を対象とした。充てん

\footnotetext{
$*$ 北海道立総合研究機構北方建築総合研究所 研究主任·工修

** 北海道立総合研究機構北方建築総合研究所 部長・博士 (工学)

*** 早稲田大学理工学術院 教授·工博
}

Researcher, Hokkaido Research Organization Northern Regional Building Research Institute, M. Eng.

General Manager, Hokkaido Research Organization Northern Regional Building Research Institute, Dr. Eng.

Prof., Department of Architecture, Waseda Univ., Dr. Eng. 
工法では、厚さ $55 \mathrm{~mm}$ の断熱材を室内側と外気側にそれぞれ配置し た半充てん壁体、100 $\mathrm{mm}$ の断熱材を配置した充てん壁体の 3 種類を 試験体とした。外張断熱工法では、外張断熱材の厚さをそれぞれ 25 $\mathrm{mm} 、 60 \mathrm{~mm} 、 100 \mathrm{~mm}$ とした壁体の 3 種類を試験体とした。付加断熱工法 では、100 mmの断熱材を充てんした上で、付加断熱材の厚さをそれ ぞれ $25 \mathrm{~mm} 、 60 \mathrm{~mm} 、 100 \mathrm{~mm}$ とした壁体の 3 種類を試験体とした。さら に断熱材を有しない場合として無断熱壁体を加え、計 10 種類を試 験体とした。なお試験体 1 種類につき、屋外加熱、屋内加熱それぞ れ 1 体ずつ計 2 体の試験を行った。

試験体の共通仕様として、外装材は市販品の窒業系サイディング 厚さ $15 \mathrm{~mm}$ 、通気層は通気胴縁により厚さ $18 \mathrm{~mm}$ 、内装材はせっこう ボード厚さ $9.5 \mathrm{~mm}$ とし、充てん断熱材は袋入りロッククール $24 \mathrm{~K} 、$ 外張断熱材はロックウール $40 \mathrm{~K}$ を用いた。防風層は透湿防水シート 厚さ $0.17 \mathrm{~mm}$ 、防湿層はポリエチレンシート厚さ $0.2 \mathrm{~mm}$ を用いて、木 柱や枠材等の木材は、ホワイトウッドと呼ばれる北欧産材を使用し た。なお小材の重量含水率は $10 \sim 15 \% \mathrm{wt}$ の範囲にあり、その他の 各種建材は含水率調整を行わず、市販品を気乾させた上で用いた。

\section{3 測定項目}

\section{1) 遮熱性 · 遮炎性}

壁体内部の温度分布を把握するため、図 1 中に示す温度測定位置 に K タイプ $(\mathrm{CA})$ 熱電対を設置して、試験体裏面の温度、壁体内 部の断熱材および内装材の各表面温度を測定した。壁体の遮熱性は、 試験体裏面の温度が国土交通省指定性能評価機関の「防耐火性能試 験・評価業務方法書」2)に定められた規定值 (平均: 初期温度 $+140 \mathrm{~K}$ 、 最高 : 初期温度+180K）に達する時間で評価し、試験開始後 30 分、 45 分、60 分における試験体裏面温度上昇の平均值および最高值を 参考として用いた。遮炎性は非加熱面側からの目視観察で確認した。

\section{2) 非損傷性}

非損傷性は載荷と変形評価を必要とするため、小型試験では直接 把握できない。ただ非損傷性は木柱が長期許容応力度の荷重に対し 座屈するか否かで決まるため、木柱の損傷の程度が大きく影響する。 そこで試験終了後の木柱に対し、最も炭化が進んでいる部分を目視 で確認し、断面寸法が最も小さい部分（最小断面と称す。）の断面積 と断面二次モーメントを求め、試験前を $100 \%$ とした時の断面積と 断面二次モーメントの残存割合を算出した。

表 1 試験体の仕様一覧

\begin{tabular}{|c|c|c|c|c|c|c|c|c|c|}
\hline \multirow{2}{*}{$\begin{array}{l}\text { 試験 } \\
\text { 体NNo. }\end{array}$} & \multirow{2}{*}{\begin{tabular}{|l} 
断熱 \\
工法
\end{tabular}} & \multirow[t]{2}{*}{ 試験体仕様 } & \multirow[b]{2}{*}{ 外張断熱材 } & & \multicolumn{3}{|c|}{ 壁体の熱貫流抵抗 ${ }^{*}\left(\mathrm{~m}^{2} \cdot \mathrm{K} / \mathrm{W}\right)$} & \multicolumn{2}{|c|}{ 試験体の共通仕様 } \\
\hline & & & & 充てん断熱材 & 試験体 * & 試験体断熱部” & 実大仕様※ & \multirow{8}{*}{\begin{tabular}{|l} 
外装材 \\
通気層 \\
内装材 \\
充てん断熱材 \\
外張断熱材 \\
防風層 \\
防湿層 \\
木柱・枠材
\end{tabular}} & \multirow{2}{*}{$\begin{array}{l}: \text { 窯業系サイディング（厚さ } 15 \mathrm{~mm} ・ \text { 市販品） } \\
\text { : 通気胴縁（厚さ } 18 \mathrm{~mm}) \\
: \text { せっこうボード (厚さ } 9.5 \mathrm{~mm})\end{array}$} \\
\hline 1 & 無断熱 & 無断熱壁体 & \multirow{4}{*}{ なし } & なし & 0.41 & 0.35 & 0.32 & & \\
\hline $2-1$ & \multirow{3}{*}{$\begin{array}{l}\text { 充てん } \\
\text { 断熱 } \\
\text { 工法 } \\
\end{array}$} & $55 \mathrm{~mm}$ 室内側配置 & & $24 \mathrm{~K} 55 \mathrm{~mm}$ & 1.67 & 1.80 & 1.49 & & : 袋入りロッククール $24 \mathrm{~K} \lambda=0.038 \mathrm{~W} / \mathrm{m}^{2} \mathrm{~K}$ \\
\hline $2-2$ & & $55 \mathrm{~mm}$ 外気側配置 & & $24 \mathrm{~K} 55 \mathrm{~mm}$ & 1.73 & 1.89 & 1.55 & & : ロックウール $40 \mathrm{~K} \quad \lambda=0.038 \mathrm{~W} / \mathrm{m}^{2} \mathrm{~K}$ \\
\hline $2-3$ & & $100 \mathrm{~mm}$ 充てん & & $24 \mathrm{~K} 100 \mathrm{~mm}$ & 2.39 & 2.99 & 2.19 & & : 透湿防水シート厚さ $0.17 \mathrm{~mm}$ \\
\hline 3-1 & \multirow{3}{*}{$\begin{array}{l}\text { 外張 } \\
\text { 断熱 } \\
\text { 工法 }\end{array}$} & $25 \mathrm{~mm}$ 外張 & $40 \mathrm{~K} 25 \mathrm{~mm}$ & \multirow{3}{*}{ なし } & 1.19 & 1.10 & 0.95 & & : ポリエチレンシート厚さ $0.2 \mathrm{~mm}$ \\
\hline $3-2$ & & $60 \mathrm{~mm}$ 外張 & $40 \mathrm{~K} 60 \mathrm{~mm}$ & & 2.13 & 2.02 & 1.78 & & $\begin{array}{l}\text { ：ホワイトウッド (北欧産材) を使用 } \\
\text { 木材の重量含水率は } 10 \sim 15 \% \text { wt } の \text { 範囲 }\end{array}$ \\
\hline 3-3 & & $100 \mathrm{~mm}$ 外張 & $40 \mathrm{~K} 100 \mathrm{~mm}$ & & 3.19 & 3.08 & 2.71 & & \\
\hline 4-1 & \multirow{3}{*}{$\begin{array}{l}\text { 付加 } \\
\text { 断熱 } \\
\text { 工法 }\end{array}$} & $25 \mathrm{~mm}$ 付加 & $40 \mathrm{~K} 25 \mathrm{~mm}$ & \multirow{3}{*}{$24 \mathrm{~K} 100 \mathrm{~mm}$} & 3.13 & 3.64 & 2.92 & \multirow{3}{*}{\multicolumn{2}{|c|}{ ※木材以外の各種建材は特に含水率調整は行わず、市販品 }} \\
\hline $4-2$ & & $60 \mathrm{~mm}$ 付加 & $40 \mathrm{~K} 60 \mathrm{~mm}$ & & 4.11 & 4.57 & 3.83 & & \\
\hline 4-3 & & $100 \mathrm{~mm}$ 付加 & $40 \mathrm{~K} 100 \mathrm{~mm}$ & & 5.20 & 5.62 & 4.83 & & \\
\hline
\end{tabular}

※実際の壁体と試験体では、断熱材と木材部の見付面積の割合が異なる。また試験時、試験体の通気層の上端と下端を塞いだうえで試験を行う。これらの理由より、実際の壁体と試験体 では熱貫流抵抗の值が異なる。ここでは、次に示す算出方法にて、試験体、試験体断熱部、実大仕様の3つの值をそれぞれ求めた

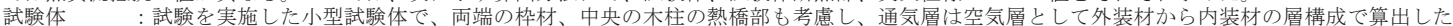

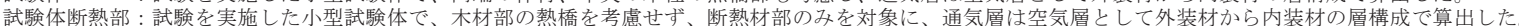

実大仕様 : 実際の壁体仕様で熱橋 $(105 \mathrm{~mm} \times 105 \mathrm{~mm}$ の木柱を $1,820 \mathrm{~mm}$ 間隔で、柱間に $45 \mathrm{~mm} \times 105 \mathrm{~mm}$ の間柱を $455 \mathrm{~mm}$ 間隔で設置)を考慮し、通気層から内装材の層構成で算出した。

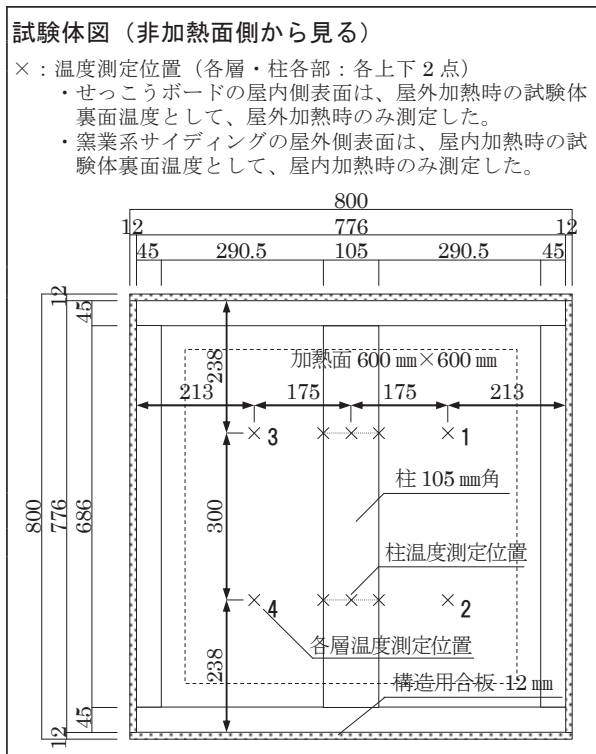

※防風層:透湿防水シートを施工する木柱の屋外側に面する層

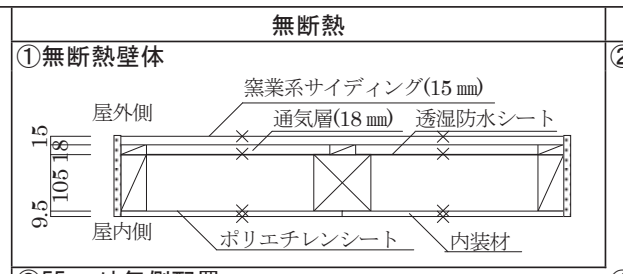

(3)55 mm外気側配置

窯業系サイディング $(15 \mathrm{~mm})$ 通気層 $(18 \mathrm{~mm})$ 屋外側 ロックウール断熱材 $(55 \mathrm{~mm})$ 透湿防水シート

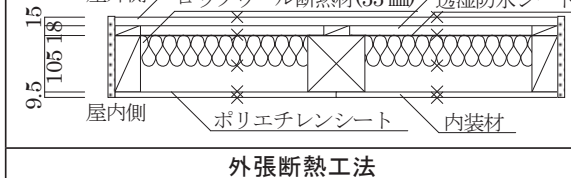
(4) $100 \mathrm{~mm}$ 充てん 屋外側 塞業系サイディング $(15 \mathrm{~mm}))$ 通気層 $(18 \mathrm{~mm})$

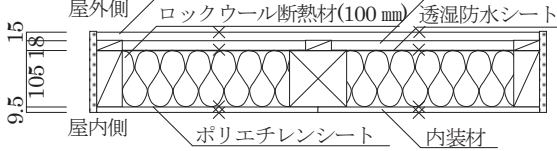

の 屋内側 ポリエチレンシート 内装材 付加断熱工法

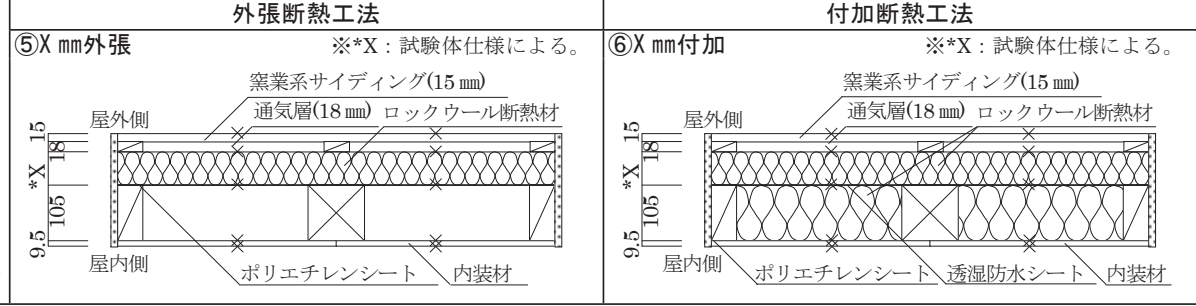

図 1 試験体概要および断熱工法ごとの試験体仕様 
また本研究で対象とする大壁の木造断熱壁体では、木柱は内外装 材や断熱材に被覆された状態で火熱を受ける。さらに断熱工法によ り木柱と断熱材の位置関係、木柱の被覆状況が異なるため、木柱各 箇所での火熱の受け方は一様ではない。断熱工法による木柱の火熱 の受け方の違いを把握するため、表 2 に示すように試験前の木柱の 表面に熱電対を設置し、柱正面、柱角部、柱側面の表面付近温度 (以 下、それぞれ柱正面温度、柱角部温度、柱側面温度と称す。）を測定 した。柱正面温度、柱角部温度、柱側面温度が、それぞれ木材の着 火温度 $\left(260^{\circ} \mathrm{C}\right.$ と仮定する)を上回った時間を、その点での木柱表面の 着火時間とし、この着火時間から試験終了までの時間を木柱の燃焼 時間とした。既往研究 3)を参考に、図 2 に示寸ように、その測定点 での試験終了後の炭化深さを計測した。さらに測定点ごとに炭化深 さを木柱の燃焼時間で除した值の平均值を着火後の炭化速度とした。

表 2 木柱表面の温度測定位置

\begin{tabular}{|c|c|c|c|}
\hline \multicolumn{2}{|c|}{ 屋外加熱の場合 } & \multicolumn{2}{|c|}{ 屋内加熱の場合 } \\
\hline $\begin{array}{l}\text { 充てん工法 } \\
\text { (無断熱) }\end{array}$ & $\begin{array}{l}\text { 外張断熱工法 } \\
\text { (付加断熱工法) }\end{array}$ & $\begin{array}{l}\text { 充てん工法 } \\
\text { (無断熱) }\end{array}$ & $\begin{array}{l}\text { 外張断熱工法 } \\
\text { (付加断熱工法) }\end{array}$ \\
\hline 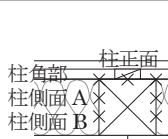 & 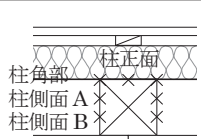 & 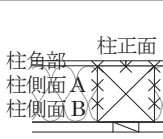 & 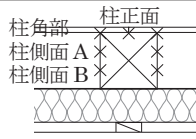 \\
\hline
\end{tabular}

$\times$ : 温度測定位置（柱正面：各上下 2 点、柱側面 $\mathrm{A} \sim \mathrm{C}$ ：左右 2 面各上下計 4 点）

なお温度測定位置の上下方向の位置は、図 1 中に示寸。

\begin{tabular}{|c|c|}
\hline 炭化深さ1 & 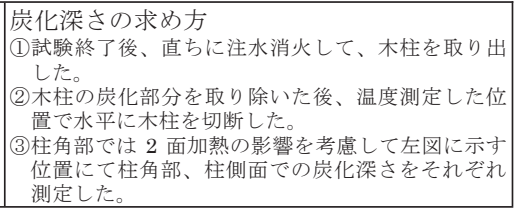 \\
\hline
\end{tabular}

図 2 炭化深さ測定位置

\section{3. 充てん断熱工法の試験結果及び考察}

3-1 屋外加熱

1) 遮熱性 · 遮炎性

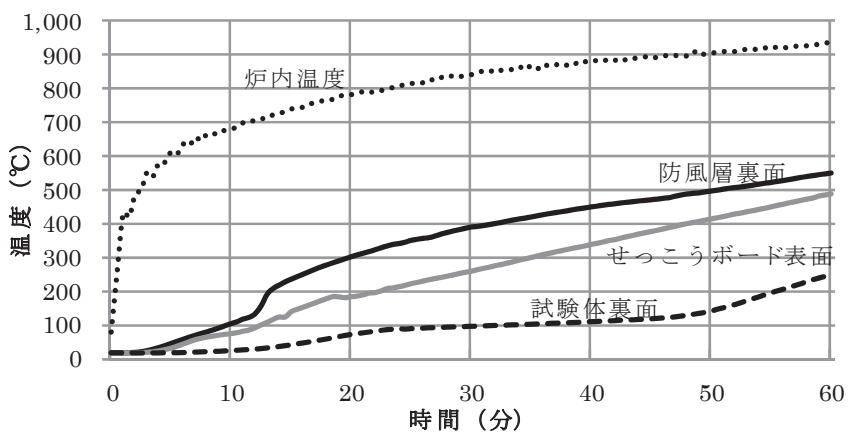

図 3 各層の平均温度の推移 (1. 無断熱壁体・屋外加熱)
断熱材が充てんされることで加熱側から非加熱側への熱の移動が 妨げられ、断熱材の加熱面側では温度がより高く、非加熱面側では 温度がより低くなった（図 3 ・図 4 )。従って、外装材等の面材が脱 落せず保持されていれば、壁体の遮熱性は断熱化されることで向上 する。但し、断熱化されることで、断熱材の加熱面側にある外装材 は、裏面側の下地となる通気胴縁や留付材を含め高温に曝されるこ とになり、実大試験では脱落の危険性が高くなると考えられる。

遮炎性および遮熱性の検討結果を表 3 に示す。無断熱壁体は、45 分での裏面温度上昇度が平均 $100 \mathrm{~K}$ 程度に留まり、45 分の遮熱性を 有している。また無断熱壁体に厚さ $55 \mathrm{~mm}$ の断熱材を充てんするこ とで、壁体の熱貫流抵抗は $0.41 \mathrm{~m}^{2} \mathrm{~K} / \mathrm{W}$ から $1.67 \mathrm{~m}^{2} \mathrm{~K} / \mathrm{W} \sim 1.73 \mathrm{~m}^{2}$ $\mathrm{K} / \mathrm{W}$ となり、壁体の断熱性能を高めることで 60 分の遮熱性を確保

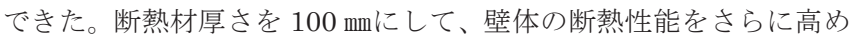
ても、裏面温度上昇度は $10 \mathrm{~K}$ 程度しか低下しなかった。従って、こ の構成の断熱壁体では $55 \mathrm{~mm}$ の断熱材を充てんした段階で、60 分の 遮熱性を有するだけの壁体の断熱性は十分に得られると考えられる。

\section{2) 非損傷性}

試験終了後（60 分加熱）の木柱の最小断面は、断熱材位置や厚さ により柱断面の形状が異なった（表 4 ）。最小断面の断面積の残存割 合（以下、柱断面残存率と称す。）に大きな差は見られなかったが、 断面二次モーメントは、無断熱壁体が最も大きな值となり、断熱材 を充てんすることで非損傷性に不利な影響を及ぼす結果となった。

木柱の柱角部温度、柱側面温度（図 5 ）を見ると、無断熱壁体で は熱が非加熱面側へ抜け、局部的に温度が高くなる部分は見られな かった。一方、断熱材が充てんされると、木柱の加熱面側に近い柱 角部、柱側面 A の位置で、木材の着火温度 $\left(260^{\circ} \mathrm{C}\right)$ に達する時間 が無断熱壁体より早く、着火後も高い温度で推移している。

特に $55 \mathrm{~mm}$ 外気側配置壁体、100 mm充てん壁体では、断熱材の加 熱面側表面（以下、断熱材表面と称寸。）は、ともに防風層の非加熱 面側（以下、防風層裏面と称す。）に位置し、断熱材で遮られた熱に よって木柱の加熱面側に近い位置が無断熱壁体に比べ激しく燃焼し

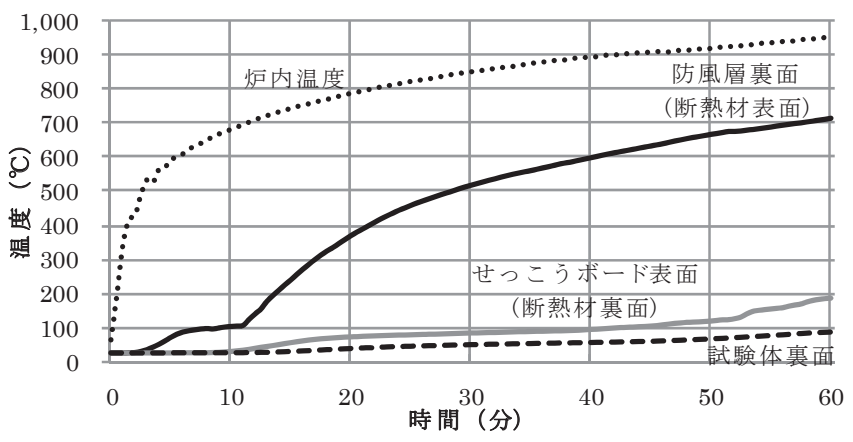

図 4 各層の平均温度の推移 $(2-3.100 \mathrm{~mm}$ 充てん・屋外加熱 $)$

表 3 遮炎性および遮熱性の検討結果（充てん断熱工法・屋外加熱）

\begin{tabular}{|c|c|c|c|c|c|c|c|c|c|c|c|c|c|c|c|c|}
\hline \multirow{3}{*}{\begin{tabular}{|l|} 
試験 \\
体NNo.
\end{tabular}} & \multirow{3}{*}{$\begin{array}{l}\text { 断熱 } \\
\text { 工法 }\end{array}$} & \multirow[t]{3}{*}{ 試験体仕様 } & \multirow{2}{*}{\multicolumn{2}{|c|}{$\begin{array}{c}\text { 試験体の熱貫流抵抗 } \\
\left(\mathrm{m}^{2} \cdot \mathrm{K} / \mathrm{W}\right) \\
\end{array}$}} & \multirow{3}{*}{$\begin{array}{c}\text { 遮炎性 } \\
\text { 炎の貫通 } \\
\text { の有無 }\end{array}$} & \multirow{2}{*}{\multicolumn{4}{|c|}{$\begin{array}{c}\text { 各層の温度上昇度が遮熱性の規定値を超える時間（分） } \\
\text { （規定值：平均 } 140 \mathrm{~K} \text { または最高 } 180 \mathrm{~K} ）\end{array}$}} & \multicolumn{7}{|c|}{ 試験体裏面の温度上昇度（K） } \\
\hline & & & & & & & & & & \multirow{2}{*}{$\begin{array}{l}\text { 初期 } \\
\text { 温度 }\end{array}$} & \multicolumn{2}{|c|}{30 分 } & \multicolumn{2}{|c|}{45 分 } & \multicolumn{2}{|c|}{60 分 } \\
\hline & & & 試験体 & \begin{tabular}{|c|} 
試験体断熱部 \\
\end{tabular} & & \begin{tabular}{|l|} 
防風層裏面* \\
\end{tabular} & 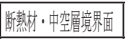 & GB 表面** & 試験体裏面 & & 平均 & 最高 & 平均 & 最高 & 平均 & 最高 \\
\hline 1 & \begin{tabular}{|l|l} 
無断熱 \\
\end{tabular} & 無断熱壁体 & 0.41 & 0.35 & なし & 12.5 & - & 16.3 & 51.1 & 15 & 78 & 84 & 100 & 109 & 231 & 270 \\
\hline $2-1$ & 充てん & $55 \mathrm{~mm}$ 室内側配置 & 1.67 & 1.80 & なし & 13.2 & 13.8 & 39.2 & 超えず & 23 & 33 & 37 & 59 & 71 & 75 & 78 \\
\hline $2-2$ & 断熱 & $55 \mathrm{~mm}$ 外気側配置 & 1.73 & 1.89 & なし & 13.6 & 25.5 & 44.1 & 超えず & 21 & 40 & 46 & 70 & 78 & 78 & 85 \\
\hline $2-3$ & 工法 & $100 \mathrm{~mm}$ 充てん & 2.39 & 2.99 & なし & 12.5 & - & 53.2 & 超えず & 23 & 26 & 27 & 37 & 40 & 66 & 74 \\
\hline
\end{tabular}


たと考えられる。その結果、最も影響を与える柱の周縁部の欠損が 大きくなり、断面二次モーメントは無断熱壁体に比べ低くなったと 考えられる。一方、 $55 \mathrm{~mm}$ 外気側配置壁体は断熱材が薄く、かつ非加 熱面側では木柱は空気層に露出しており放熱が促されたため、柱側 面 B の位置では、100 mm充てん壁体に比べ低い温度推移となった。 $55 \mathrm{~mm}$ 室内側配置壁体では、断熱材の加熱面側にある防風層裏面、木 部が空気層に露出している柱角部、柱側面 $\mathrm{A}$ でほぼ同じ温度推移と なった。断熱材により熱が妨げられ、断熱材の加熱面側で一様な熱 分布になっていると考えられる。

柱角部での着火後の炭化速度は、無断熱壁体では $0.46 \mathrm{~mm} /$ 分に対 し、充てん断熱壁体ではいずれも大きくなった。炭化速度からも、 充てん断熱材により、柱角部での燃焼が進んでいることが分かる。

柱側面 B では、 $55 \mathrm{~mm}$ 外気側配置壁体、100 mm充てん壁体で炭化が なく、木柱の被覆効果が確認された。炭化が見られた無断熱壁体、
$55 \mathrm{~mm}$ 室内側配置壁体では柱側面の着火後の炭化速度はそれぞれ $0.15 \mathrm{~mm} /$ 分、 $0.13 \mathrm{~mm} /$ 分となった。2 面加熱を受ける柱角部と比心゙、 柱側面 B では側面部からの 1 面加熱でかつ受ける熱量が低いため、 着火後の炭化速度は柱角部の半分以下になったと考えられる。

以上より、充てん断熱工法では、断熱材の位置、厚さにより、断 熱材と木柱との位置関係、壁体内の温度分布が変化し、木柱が受け る損傷状況が異なる。断熱材が充てんされることで非加熱面側への 放熱が妨げられ、断熱材の加熱面側では温度が高くなる。断熱材の 加熱面側の温度は、断熱材表面の位置が加熱面に近いほど高温にな り、その位置での木柱の断面欠損を大きくする傾向がある。その結 果、木柱を含む層から非加熱面側への熱損失が大きい無断熱壁体が、 他の充てん壁体に比べ、最も残存断面の断面二次モーメントが大き くなった。

よって、断熱材を充てんすることが、必ずしも、壁体の非損傷性

表 4 木柱最小断面の断面積残存率と断面二次モーメント、木柱の炭化速度

\begin{tabular}{|c|c|c|c|c|c|c|c|c|c|}
\hline \multirow{2}{*}{\multicolumn{2}{|c|}{$\begin{array}{c}\text { 加熱面 } \\
\text { 断熱工法 } \\
\end{array}$}} & \multicolumn{4}{|c|}{ 屋外加熱 } & \multicolumn{4}{|c|}{ 屋内加熱 } \\
\hline & & \multirow{2}{*}{$\begin{array}{c}\text { 無断熱 } \\
\text { 1.無断熱壁体 }\end{array}$} & \multicolumn{3}{|c|}{ 充てん断熱工法 } & \multirow{2}{*}{$\begin{array}{c}\text { 無断熱 } \\
1 \text {.無断熱壁体 }\end{array}$} & \multicolumn{3}{|c|}{ 充てん断熱工法 } \\
\hline 試験体仕様 & & & 2-1.55 血室内側配置 & 2-2.55 mm外気側配置 & 2-3.100 m充てん & & 2-1.55 血室内側配置 & 2-2.55 m外気側配置 & 2-3.100 m充てん \\
\hline 木柱断面写真 & 最小断面 & & 1 & & & & & & \\
\hline 断面積残存率 & 最小断面 & $74.0 \%$ & $72.6 \%$ & $73.2 \%$ & $71.8 \%$ & $31.3 \%$ & $30.2 \%$ & $35.8 \%$ & $25.9 \%$ \\
\hline 断面二次モーメント(m $\left.\mathrm{m}^{4}\right)$ & 最小断面 & $5.86 \times 10^{6}$ & $5.19 \times 10^{6}$ & $4.31 \times 10^{6}$ & $4.47 \times 10^{6}$ & $1.06 \times 10^{6}$ & $0.87 \times 10^{6}$ & $1.41 \times 10^{6}$ & $0.73 \times 10^{6}$ \\
\hline 断面二次モーメント残存率 & 最小断面 & $57.8 \%$ & $51.3 \%$ & $42.6 \%$ & $44.1 \%$ & $10.4 \%$ & $8.6 \%$ & $14.0 \%$ & $7.2 \%$ \\
\hline 柱角部·炭化速度(mm/分) & 温度測定位置 & 0.46 & 0.51 & 0.54 & 0.56 & 0.83 & 0.72 & 0.82 & 欠測 \\
\hline 柱側面·炭化速度(m/ $\mathrm{m} /$ 分) & 温度測定位置 & 0.15 & 0.13 & 炭化部なし & 炭化部なし & - & - & - & - \\
\hline
\end{tabular}

※炭化速度(mm/分) : 測定点ごとに、炭化深さ $(\mathrm{mm})$ を木柱の燃焼時間(分)で除した着火後の炭化速度の平均値。

※屋内加熱では柱の損傷が柱裏面まで及び、柱側面での加熱条件が柱側面からの一面加熱でなくなったため、柱側面の炭化速度は求めないこととした。

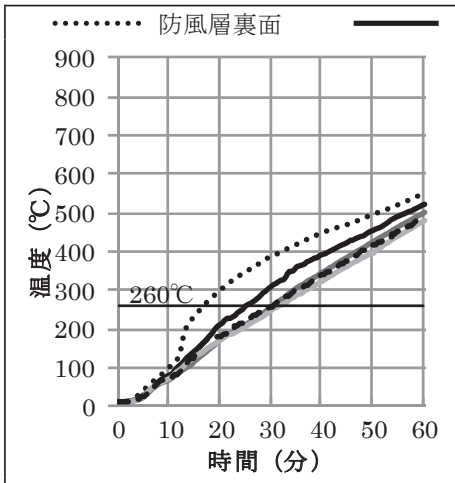

1.無断熱

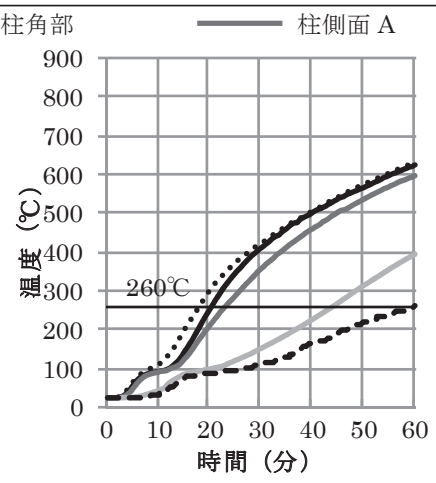

$2-1.55 \mathrm{~mm}$ 室内側配置

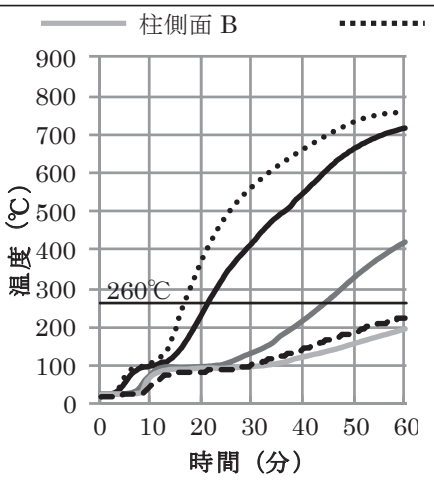

$2-2.55 \mathrm{~mm}$ 外気側配置

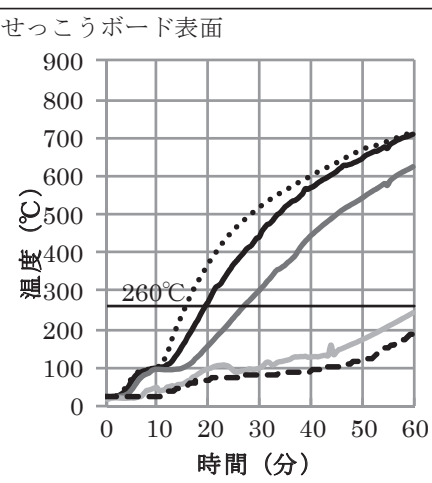

2-3.100 mm充てん

図 5 木柱側面部の平均温度推移（充てん断熱工法・屋外加熱）

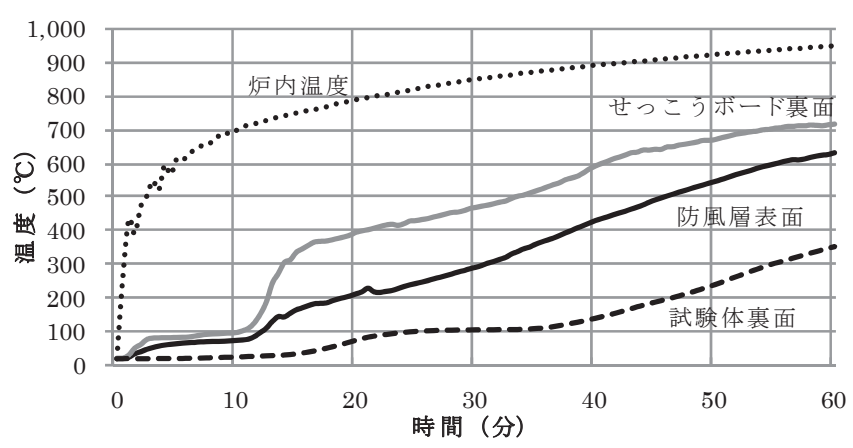

図 6 各層の平均温度の推移（1.無断熱・屋内加熱）

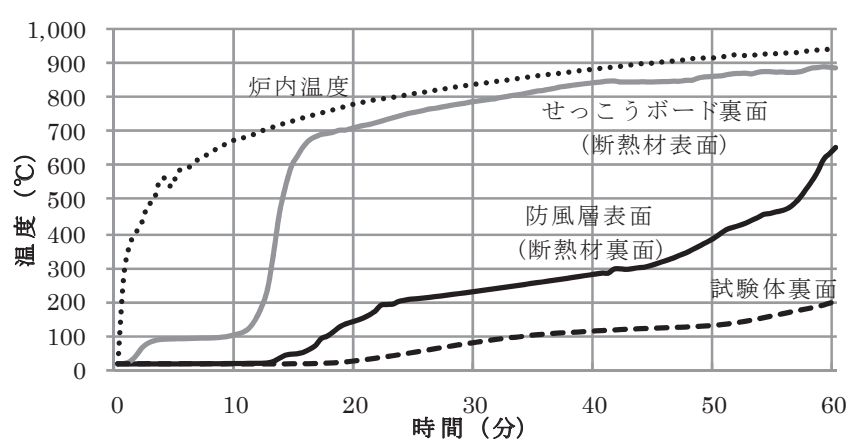

図 7 各層の平均温度の推移 $(2-3.100 \mathrm{~mm}$ 充てん・屋内加熱) 
を高めることにならないことが分かった。今後、既往研究 4) 5) にあ るように、柱内部の温度分布を測定し、ヤング係数の低下を加味し た力学的な検討や実大試験による検証が必要である。

\section{3-2 屋内加熱}

\section{1) 遮熱性・遮炎性}

屋内加熱では、断熱材が充てんされることで加熱側のせっこうボ ードが高温に曝される（図6・図 7 )。しかし無断熱壁体と $100 \mathrm{~mm}$ 充てん壁体で、せっこうボード裏面の温度推移が $100^{\circ} \mathrm{C}$ より温度上 昇し始める時間はほとんど変わらなかった。

遮炎性および遮熱性の検討結果を表 5 に示す。加熱側被覆がせっ こうボードのみであるため、中空部への火炎貫通は屋外加熱時より も早く、裏面温度も屋外加熱時より概して顕著である。防火構造で は屋内加熱を想定する必要はなく、準耐火構造でも屋内加熱では遮 熱性は要求されないが、厚さ $55 \mathrm{~mm}$ 以上の断熱材を充てんした壁体 で、45 分の遮熱性を保持できている。無断熱壁体で 60 分の遮炎性 は有しており、屋内加熱に対しても壁体の防耐火性能は非損傷性で 決まると考えられる。

\section{2) 非損傷性}

試験終了後（60 分加熱）の木柱の最小断面は、非加熱側である木 材裏面での断面欠損もあり、いずれも断面積残存率が $30 \%$ 前後で、 木柱の損傷が激しかった（表 4)。屋内加熱 60 分に対して、内装材 がせっこうボード $9.5 \mathrm{~mm}$ では不十分であったと考えられる。

柱角部温度および柱側面温度（図 8 ）を見ると、柱角部および柱 側面各部における木材の着火温度に達する時間は、断熱材を充てん してもほとんど変わらず、断熱材による被覆効果はあまり見られな かった。内装側のせっこうボードにできた亀裂により、火炎が壁体 内に侵入し、断熱材が存在しても火熱が木柱と断熱材の間の隙間を 通って、柱側面の表面を加熱したと考えられる。

そこで $100 \mathrm{~mm}$ 充てん壁体を対象に、火熱が木柱と断熱材の間の隙 間を通らないように、充てん断熱材の幅を柱間の間隔より $10 \mathrm{~mm}$ 程 度広くして、充てん断熱材が柱側面に密着するように施工して、再 度試験を行い比較した（表 6 ）。充てん断熱材を柱側面に密着させる ことで、充てん断熱材による木柱の被覆効果が発現され、非損傷性 が大きく向上した。

屋内加熱では内装材がせっこうボードだけになる場合が多く、火

表 5 遮炎性および遮熱性の検討結果（充てん断熱工法・屋内加熱）

\begin{tabular}{|c|c|c|c|c|c|c|c|c|c|c|c|c|c|c|c|c|}
\hline \multirow{3}{*}{ 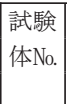 } & \multirow{3}{*}{$\begin{array}{l}\text { 断熱 } \\
\text { 工法 }\end{array}$} & \multirow[t]{3}{*}{ 試験体仕様 } & \multirow{2}{*}{\multicolumn{2}{|c|}{$\begin{array}{c}\text { 試験体の熱貫流抵抗 } \\
\left(\mathrm{m}^{2} \cdot \mathrm{K} / \mathrm{W}\right)\end{array}$}} & \multirow{3}{*}{$\begin{array}{c}\text { 遮炎性 } \\
\text { 炎の貫通 } \\
\text { の有無 }\end{array}$} & \multirow{2}{*}{\multicolumn{4}{|c|}{$\begin{array}{l}\text { 各層の温度上昇度が遮熱性の規定值を超える時間（分） } \\
\quad \text { （規定值：平均 } 140 \mathrm{~K} \text { または最高 } 180 \mathrm{~K} ）\end{array}$}} & \multicolumn{7}{|c|}{ 試験体裏面の温度上昇度（K） } \\
\hline & & & & & & & & & & \multirow{2}{*}{$\begin{array}{l}\text { 初期 } \\
\text { 温度 }\end{array}$} & \multicolumn{2}{|c|}{30 分 } & \multicolumn{2}{|c|}{45 分 } & \multicolumn{2}{|c|}{60 分 } \\
\hline & & & 試験体 & \begin{tabular}{|l|} 
試験体断熱部 \\
\end{tabular} & & GB 裏面* & 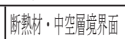 & \begin{tabular}{|l|l|} 
防風層表面** \\
\end{tabular} & 試験体裏面 & & 平均 & 最高 & 平均 & 最高 & 平均 & 最高 \\
\hline 1 & \begin{tabular}{|l|l} 
無断熱 \\
\end{tabular} & 無断熱壁体 & 0.41 & 0.35 & なし & 12.1 & - & 14.7 & 42.1 & 18 & 86 & 88 & 168 & 222 & 333 & 430 \\
\hline $2-1$ & 充てん & 55 mm室内側配置 & 1.67 & 1.80 & なし & 11.5 & 15.4 & 16.3 & 46.1 & 20 & 71 & 85 & 112 & 157 & 233 & 393 \\
\hline $2-2$ & 断熱 & $55 \mathrm{~mm}$ 外気側配置 & 1.73 & 1.89 & なし & 11.7 & 11.8 & 17.9 & 48.9 & 20 & 73 & 80 & 92 & 116 & 232 & 438 \\
\hline $2-3$ & 工法 & $100 \mathrm{~mm}$ 充てん & 2.39 & 2.99 & なし & 11.7 & - & 20.8 & 54.7 & 17 & 63 & 78 & 104 & 111 & 183 & 245 \\
\hline
\end{tabular}
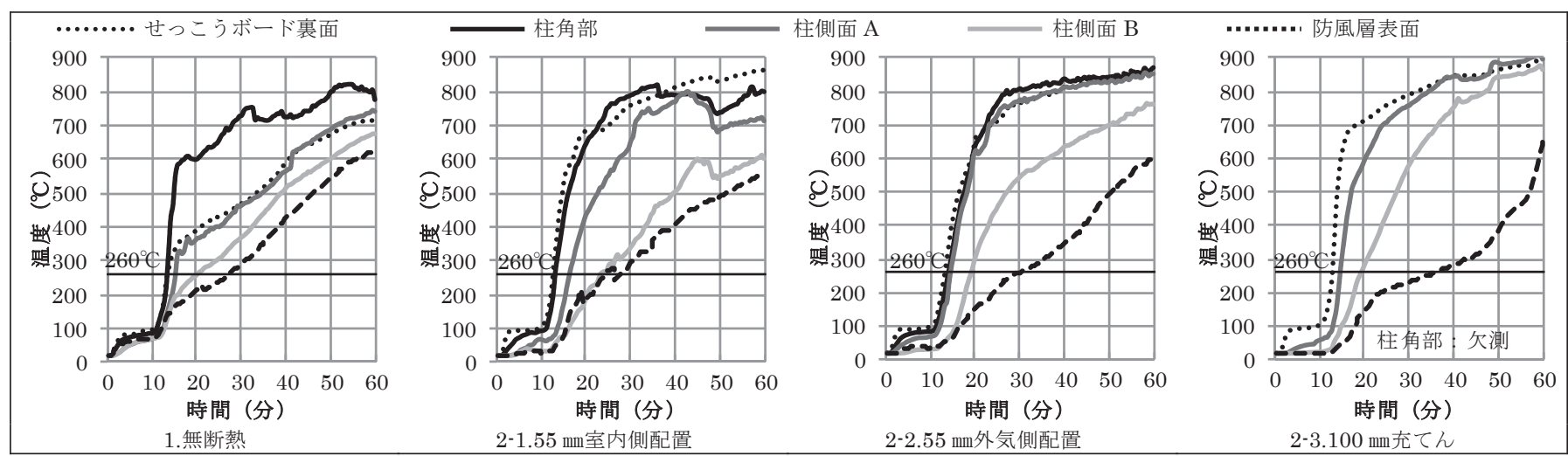

図 8 木柱側面部の平均温度推移（充てん断熱工法・屋内加熱）

表 $6100 \mathrm{~mm}$ 充てん壁体・施工法による比較

\begin{tabular}{|c|c|c|c|}
\hline \multicolumn{2}{|c|}{ 断熱工法・加熱面 } & \multicolumn{2}{|c|}{ 充てん断熱工法・屋内加熱 } \\
\hline \multicolumn{2}{|l|}{ 試験体仕様 } & 2-3.100 m充てん & $\begin{array}{l}\text { 2-3-2.100 m充てん } \\
+ \text { RW 密着 }\end{array}$ \\
\hline 木柱断面写真 & 最小断面 & & \\
\hline 断面積残存率 & 最小断面 & $25.9 \%$ & $58.1 \%$ \\
\hline 断面二次モーメント (min $\left.{ }^{4}\right)$ & 最小断面 & $0.73 \times 10^{6}$ & $2.78 \times 10^{6}$ \\
\hline 断面二次モーメント残存率 & 最小断面 & $7.2 \%$ & $27.5 \%$ \\
\hline 柱角部·炭化速度 (mm/分) & 温度测定位置 & 欠測 & 0.61 \\
\hline 柱側面·炭化速度 (mm/分) & 温度測定位置 & - & 0.21 \\
\hline
\end{tabular}

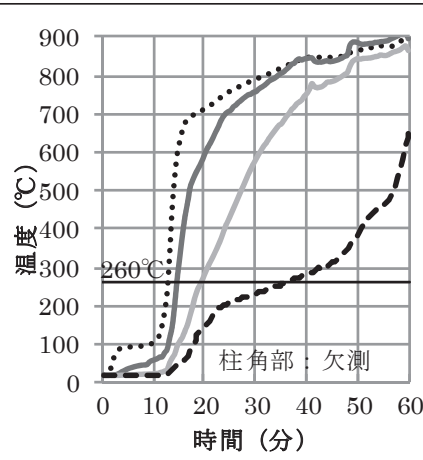

2-3.100 mm充てん

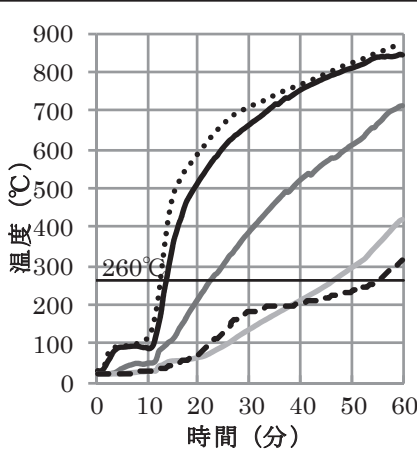

2-3-2.100 mm充てん+RW 密着
せここゔー䱜面

柱角部

柱側面 A

柱側面 B

..........

防風層表面 
炎が壁体内に侵入する可能性が高い。通常施工の充てん断熱工法で は木柱の被覆効果が期待できない場合が多いと考えられ、断熱性の 向上と防耐火性能の確保を両立させるには、断熱材を木柱に密着さ せる工夫が必要である。

\section{4. 外張断熱工法・付加断熱工法の試験結果及び考察} 4-1 屋外加熱

1) 遮熱性 · 遮炎性

遮炎性および遮熱性の検討結果を表 7 に示す。無断熱壁体に 25 $\mathrm{mm}$ 外張することで、壁体の熱貫流抵抗は $0.41 \mathrm{~m}^{2} \mathrm{~K} / \mathrm{W}$ から $1.19 \mathrm{~m}^{2}$ $\mathrm{K} / \mathrm{W}$ となり、壁体の断熱性能を高めることで 60 分の遮熱性を確保 できた。外張断熱工法では断熱材は木柱の屋外側に配置される。断 熱材が厚くなるほど、壁も厚くなり、加熱表面から試験体裏面への 距離が離れるため、遮熱性は向上する。従って、この構成の断熱壁 体で今回試験を行った範囲では、少なくとも $25 \mathrm{~mm}$ 以上の断熱材を 外張すれば、遮熱性を考慮する必要はないと考えられる。

付加断熱工法では、外張断熱工法の壁体にさらに軸間に $100 \mathrm{~mm} の$ 断熱材を充てんされるため、さらなる高断熱化となり、壁体の断熱
性能は向上する。付加断熱材がない $100 \mathrm{~mm}$ 充てん壁体で、すでに 60 分の遮熱性は得られている。従って、この構成の断熱壁体であれば、 付加断熱工法では付加断熱材の厚さを問わず、遮熱性を考慮する必 要はないと考えられる。

\section{2) 非損傷性}

外張断熱工法および付加断熱工法では、屋外加熱に対して、外張 （付加）断熱材により木柱は被覆されることになる。外張（付加） 断熱材厚さが増すことで、柱角部、柱側面の温度が低く推移し、木 材の着火温度 $\left(260^{\circ} \mathrm{C}\right)$ に達する時間が遅くなる。その結果、木材 の燃焼時間は短くなり木柱の損傷が軽減される（表 8 ・図 11）。従 って、外張（付加）断熱材厚さが増すほど、外張断熱工法および付 加断熱工法では、屋外加熱時の非損傷性が向上する。

木柱が最も加熱を受ける柱正面、柱角部における最高温度推移を みる（図 9 図 10)。外張断熱工法では、外張 $25 \mathrm{~mm}$ で 43.0 分、外 張 $60 \mathrm{~mm}$ で 49.5 分に、付加断熱工法では、付加 $25 \mathrm{~mm}$ で 27.5 分、付 加 $60 \mathrm{~mm}$ で 44.5 分、付加 $100 \mathrm{~mm}$ で 54.5 分にて、いずれも柱正面が 木材着火温度 $\left(260^{\circ} \mathrm{C}\right)$ に達している。この構成の断熱壁体で今回 試験を行った範囲では、外張（付加）断熱材の厚さを 30 分防火構

表 7 遮炎性および遮熱性の検討結果（上段：外張断熱工法・屋外加熱、下段 : 付加断熱工法 : 屋外加熱)

\begin{tabular}{|c|c|c|c|c|c|c|c|c|c|c|c|c|c|c|c|c|}
\hline \multirow{3}{*}{\begin{tabular}{|l|} 
試験 \\
体No.
\end{tabular}} & \multirow{3}{*}{$\begin{array}{l}\text { 断熱 } \\
\text { 工法 }\end{array}$} & \multirow[t]{3}{*}{ 試験体仕様 } & \multirow{2}{*}{\multicolumn{2}{|c|}{\begin{tabular}{|c|}
$\begin{array}{c}\text { 試験体の熱貫流抵抗 } \\
\left(\mathrm{m}^{2} \cdot \mathrm{K} / \mathrm{W}\right)\end{array}$ \\
\end{tabular}}} & \multirow{3}{*}{\begin{tabular}{|c|} 
遮炎性 \\
炎の貫通 \\
の有無 \\
\end{tabular}} & \multirow{2}{*}{\multicolumn{4}{|c|}{\begin{tabular}{|c|} 
各層の温度上昇度が遮熱性の規定値を超える時間（分） \\
（規定值：平均 $140 \mathrm{~K}$ または最高 $180 \mathrm{~K}$ )
\end{tabular}}} & \multicolumn{7}{|c|}{ 試験体裏面の温度上昇度 $(\mathrm{K})$} \\
\hline & & & & & & & & & & \multirow{2}{*}{ 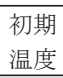 } & \multicolumn{2}{|c|}{30 分 } & \multicolumn{2}{|c|}{45 分 } & \multicolumn{2}{|c|}{60 分 } \\
\hline & & & 試験体 & 試験体断熱部 & & 外㱕断熱材表面* & 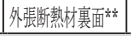 & GB 表面*** & 試験体裏面 & & 平均 & 最高 & 平均 & 最高 & 平均 & 最高 \\
\hline 1 & \begin{tabular}{|l|} 
無断熱 \\
\end{tabular} & 無断荎 & 11 & 025 & t 1 & - & 12.5 & 163 & 511 & 15 & 78 & 84 & 100 & 109 & 231 & 270 \\
\hline $3-1$ & & $25 \mathrm{~m}$ & & & & & & & & & & & & & 2 & 7 \\
\hline $3-2$ & 断熱 & $60 \mathrm{~mm}$ & & & & & & & & 2 & & & & & 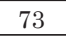 & 76 \\
\hline $3-3$ & 工法 & $100 \mathrm{~mm}$ 外張 & & & なし & 13.1 & & $\begin{array}{l}\text { 超えず } \\
\end{array}$ & 超えず & 2 & 2 & 29 & 32 & 37 & 62 & 74 \\
\hline $2-3$ & 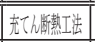 & $100 \mathrm{~mm}$ 充てん & & & なし & 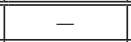 & & 53 & & 2 & 26 & 2 & 37 & 40 & 66 & 74 \\
\hline $4-1$ & 付加 & $25 \mathrm{~mm}$ & & & なし & 13.8 & & & & 2 & 1 & 2 & 35 & 37 & 62 & 69 \\
\hline 4-2 & 断熱 & $60 \mathrm{~mm}$ 付加 & & & なし & & & 超えず & 超えず & 21 & 11 & 18 & 22 & 25 & 30 & 33 \\
\hline 4-3 & 工法 & $100 \mathrm{~mm}$ 付加 & 5.20 & 5.62 & なし & 12.0 & 38.6 & 超えず & 超えず & 23 & 7 & 9 & 14 & 18 & 22 & 26 \\
\hline
\end{tabular}

表 8 木柱最小断面の断面積残存率と断面二次モーメント、木柱の炭化速度（屋外加熱）

\begin{tabular}{|c|c|c|c|c|c|c|c|c|c|}
\hline \multirow{2}{*}{\multicolumn{2}{|c|}{$\frac{\text { 断熱工法 }}{\text { 試験体仕様 }}$}} & 無断熱 & \multicolumn{3}{|c|}{ 外張断熱工法 } & |充てん断熱工法 & \multicolumn{3}{|c|}{ 付加断熱工法 } \\
\hline & & 1-1.無断熱壁体 & $3-1.25 \mathrm{~mm}$ 外張 & $3-2.60 \mathrm{~mm}$ 外張 & 3-3.100 mm外張 & |2-3.100 m m充てん & 4-1.25 mm 付加 & 4-2.60 mm付加 & 4-3.100 mm 付加 \\
\hline 木柱断面写真 & 最小断面 & & & & & & & & \\
\hline 断面積残存率 & 最小断面 & $74.0 \%$ & $92.6 \%$ & $94.3 \%$ & $99.0 \%$ & $71.8 \%$ & $82.7 \%$ & $94.2 \%$ & $99.2 \%$ \\
\hline 断面二次モーメント(m 4 $^{4}$ & 最小断面 & $5.86 \times 10^{6}$ & $8.05 \times 10^{6}$ & $8.52 \times 10^{6}$ & $9.85 \times 10^{6}$ & $4.47 \times 10^{6}$ & $6.09 \times 10^{6}$ & $8.70 \times 10^{6}$ & $10.00 \times 10^{6}$ \\
\hline 断面二次モーメント残存率 & 最小断面 & $57.8 \%$ & $79.5 \%$ & $84.1 \%$ & $97.3 \%$ & $44.1 \%$ & $60.2 \%$ & $85.9 \%$ & $98.8 \%$ \\
\hline 柱角部·炭化速度(mm/分) & 温度㵋定位置 & 0.46 & 0.48 & 0.49 & 炭化部なし & 0.56 & 0.54 & 0.53 & 炭化部なし \\
\hline 柱側面·炭化速度(mm/分) & 温度測定位置 & 0.15 & 炭化部なし & 炭化部なし & 炭化部なし & 炭化部なし & 炭化部なし & 炭化部なし & 炭化部なし \\
\hline
\end{tabular}

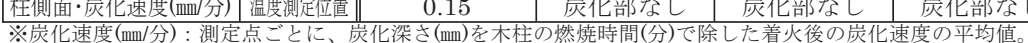

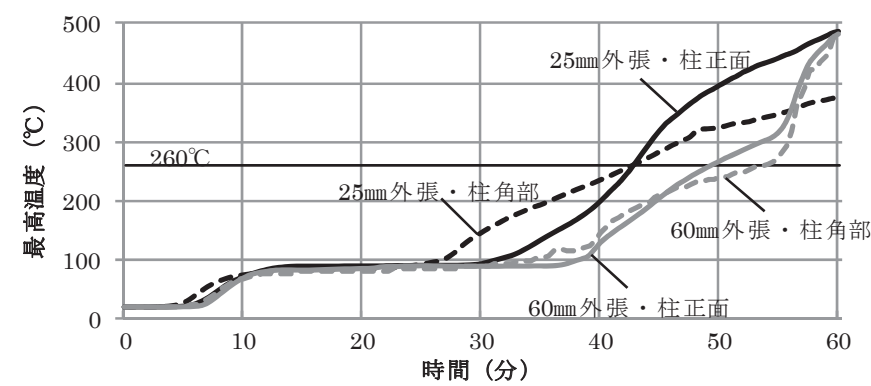

図 9 柱正面・柱角部における最高温度推移（外張断熱工法）

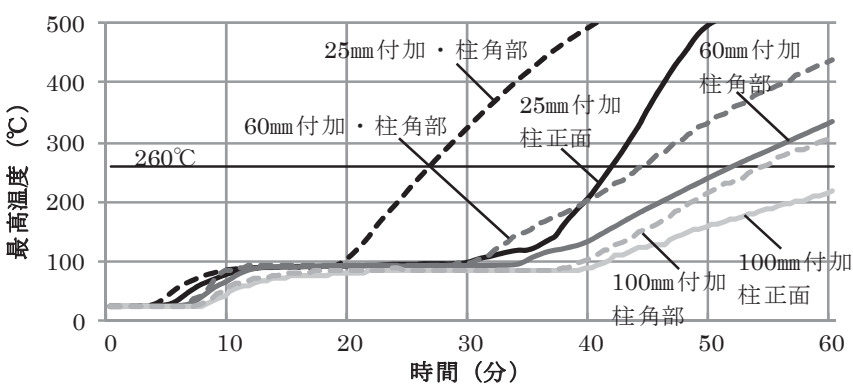

図 10 柱正面・柱角部における最高温度推移（付加断熱工法） 
造の場合は、少なくとも外張断熱工法で $25 \mathrm{~mm}$ 以上、付加断熱工法 で $60 \mathrm{~mm}$ 以上、 45 分淮耐火構造の場合は、少なくとも外張断熱工法 で $60 \mathrm{~mm}$ 以上、付加断熱工法で $100 \mathrm{~mm}$ 以上用いれば、外装材や外張 断熱材の脱落がない限り木柱に炭化部が生じなくなると考えられる。 一方、同じ外張（付加）断熱材厚さで、外張断熱工法と付加断熱 工法を比較すると、付加断熱工法の方が、木柱の中央より加熱面側 にあたる柱角部、柱側面 A で高い温度で推移し、木材の着火温度 $\left(260^{\circ} \mathrm{C}\right.$ ) に達する時間が早くなった（図 11$) 。$ 特に $25 \mathrm{~mm}$ 付加断熱 壁体では $25 \mathrm{~mm}$ 外張断熱壁体より、柱断面残存率が約 $10 \%$ 、断面二 次モーメントが約 $20 \%$ 小さくなった。外張断熱工法では、外張断熱 材の厚さに関わらず、断熱層の非加熱面側に木柱正面が位置する。

一方、付加断熱工法では充てん断熱材が存在するため、付加断熱材 の厚さが薄くなるほど、加熱面に近い木柱正面の断熱層における位 置が、相対的に加熱面側へと変化する。そのため $25 \mathrm{~mm}$ 外張断熱壁 体に、充てん断熱材を入れて $25 \mathrm{~mm}$ 付加断熱壁体とすると、非損傷 性にとって不利な結果になったと考えられる。

しかし、外張（付加）断熱材の厚さが $60 \mathrm{~mm} 、 100 \mathrm{~mm}$ と厚くなる と、付加断熱工法と外張断熱工法の非損傷性の差はほとんどなくな った。付加断熱工法では付加断熱材の厚さが増すほど、断熱層にお ける付加断熱層の割合が大きくなり、付加断熱材の断熱性能が支配 的となる。この点に加え、断熱材厚さによる木柱の被覆効果が大き くなるため、外張断熱工法に充てん断熱材を追加した時、柱角部の 温度推移は若干、高くなるが、木柱の断面欠損にはその影響がほと んど見られなくなったと考えられる。

柱角部での着火後の炭化速度は、外張断熱工法では $0.46 \sim 0.49 \mathrm{~mm}$ I分であったに対し、付加断熱工法では $0.53 \sim 0.56 \mathrm{~mm} /$ 分となった。 軸間が中空の場合に比べ、軸間に断熱材が $100 \mathrm{~mm}$ 充てんされること で、柱角部での着火時間が早くなるだけでなく、着火以後の燃焼が
進みやすくなることが分かった。

以上より、外張断熱工法、付加断熱工法ともに、外張（付加）断 熱材により木柱は被覆されるため、断熱材が厚いほど非損傷性は向 上する。さらに外張 (付加) 断熱材がある一定の厚さを確保すれば、 30 分加熱や 45 分加熱に対しては、外装材や外張断熱材の脱落がな い限り木柱に炭化部が生じなくなる可能性がある。

しかし付加断熱工法では、外張断熱工法と比べると軸間に断熱材 が充てんされることで、柱角部での着火時間、炭化速度ともに早く なる。付加断熱材厚さが十分でないと外張断熱工法に比べ非損傷性 が低下する場合がある。従って付加断熱工法においても、断熱材を 充てんすることが、必ずしも壁体の非損傷性を高めることにならな いことが分かった。

\section{4-2 屋内加熱}

\section{1) 遮熱性・遮炎性}

遮炎性および遮熱性の検討結果を表 9 に示す。前述の通り、準耐 火構造でも遮熱性は屋内加熱では要求されないが、外張断熱工法で は厚さ $25 \mathrm{~mm}$ 以上の断熱材を外張することで 45 分の遮熱性を、付加 断熱工法では 60 分の遮熱性を保持できる結果となった。すべての 外張断熱工法、付加断熱工法で遮炎性を有しており、屋内加熱に対 寸る壁体の防耐火性能は、非損傷性で決まると考えられる。

\section{2) 非損傷性}

外張断熱工法、付加断熱工法ともに試験終了後（60 分加熱）の木 柱の最小断面は、充てん断熱工法と同様に木柱の損傷が激しく、屋 内加熱 60 分に対し、内装材がせっこうボード $9.5 \mathrm{~mm}$ では不十分で あったと考えられる。しかし断面積残存率は、外張断熱工法は $30 \%$ 前後で無断熱壁体よりも小さくなる場合が見られたのに対し、付加 断熱工法ではいずれも 40\%〜 50\%に留まった（表 10）。

外張断熱工法では木柱が断熱材の加熱面側で中空層にむき出しと
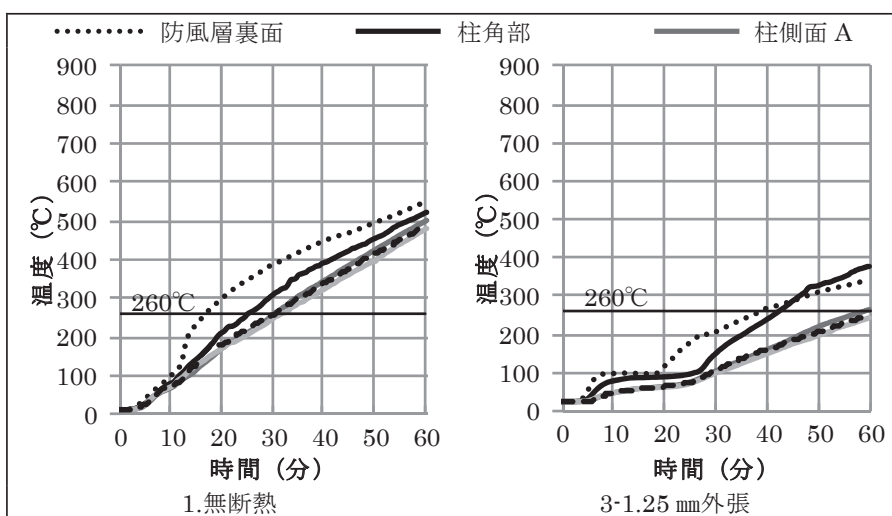

$3-1.25 \mathrm{~mm}$ 外張

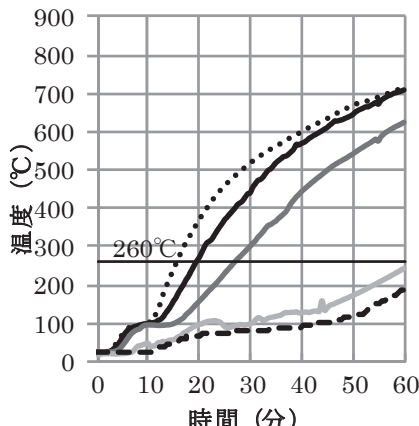

$2-3.100$

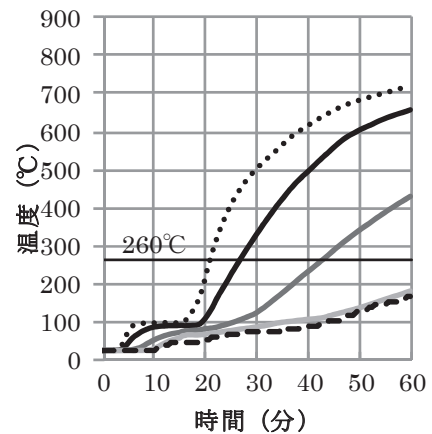

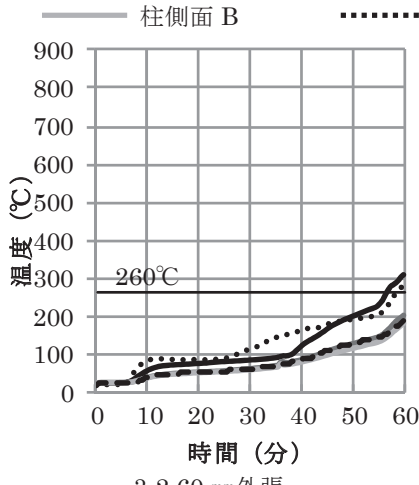

3-2.60 mm外張

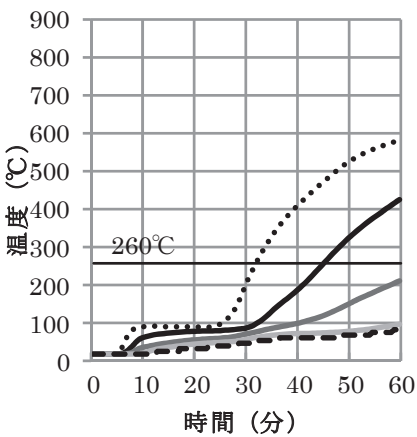

4-2.60 mm付加

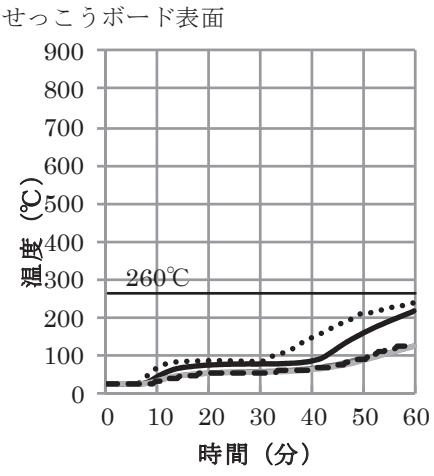

3-3.100 mm外張

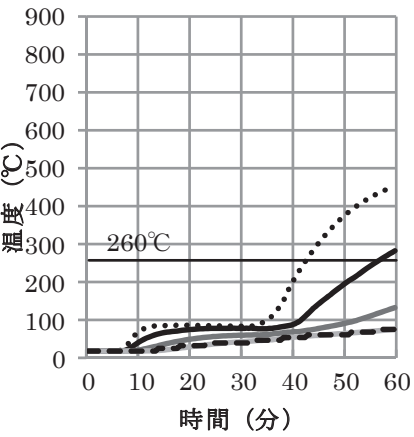

4-3.100 mm付加

図 11 木柱側面部の平均温度推移（上段：外張断熱工法・屋外加熱、下段：付加断熱工法・屋外加熱） 
なる。木柱の柱角部、柱側面の温度は、外張断熱材により裏面側一 の放熱が妨げられ、無断熱壁体に比べ一様に高い温度推移となった

(図 12)。そのため、無断熱壁体よりも木柱の損傷が進んだと考え られる。屋内加熱に対する外張断熱工法の非損傷性は、外張断熱材 によって無断熱壁体に比べ不利側に作用すると考えられる。一方、 外張断熱材厚さ $60 \mathrm{~mm}$ 以上では、木柱の断面積残存率と温度推移の
差異はあまり見られない。従って、その範囲では、外張断熱材厚さ が非損傷性に与える影響は小さいと考えられる。

付加断熱工法は、付加断熱材により断熱層における木柱の位置が 相対的に加熱面側へと変化する。そのため、付加断熱工法では充て し断熱工法に比べ木柱への加熱条件が厳しくなると予測されるが、 $100 \mathrm{~mm}$ 充てん壁体に比べ、木柱の損傷は進んでいない。外張断熱工

表 9 遮炎性および遮熱性の検討結果（上段 : 外張断熱工法・屋内加熱、下段 : 付加断熱工法 : 屋内加熱)

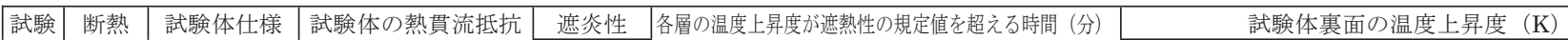

\begin{tabular}{|c|c|c|c|c|c|c|c|c|c|c|c|c|c|c|c|c|}
\hline \multirow{3}{*}{ 体No. } & \multirow{3}{*}{$\begin{array}{l}\text { 工䉼等 } \\
\text { 工法 }\end{array}$} & & \multirow{2}{*}{\multicolumn{2}{|c|}{$\begin{array}{c}\text { 試験体の熱貫流抵抗 } \\
\left(\mathrm{m}^{2} \cdot \mathrm{K} / \mathrm{W}\right)\end{array}$}} & \multirow{3}{*}{\begin{tabular}{|c} 
遮炎性 \\
炎の貫通 \\
の有無 \\
\end{tabular}} & \multirow{2}{*}{\multicolumn{4}{|c|}{$\begin{array}{l}\text { 各層の温度上昇度が遮䓡性の規定值を超える時間（分） } \\
\text { （規定值：平均 } 140 \mathrm{~K} \text { または最高 180K） }\end{array}$}} & \\
\hline & & & & & & & & & & \multirow{2}{*}{$\begin{array}{l}\text { 初期 } \\
\text { 温度 }\end{array}$} & \multicolumn{2}{|c|}{30 分 } & \multicolumn{2}{|c|}{45 分 } & \multicolumn{2}{|c|}{60 分 } \\
\hline & & & 試験体 & 圾験体断熱部 & & GB 表面* & 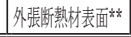 & 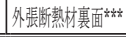 & 試験体裏面 & & 平均 & 最蒠 & 平坛 & 最 & 平土 & 最高 \\
\hline 1 & \begin{tabular}{|l|l} 
無断熱 \\
\end{tabular} & 無断熱 & 0.41 & 0.35 & なし & 12.1 & 14.7 & - & 42.1 & 18 & 86 & 88 & 168 & 22 & 33 & 430 \\
\hline 3-1 & 外張 & $25 \mathrm{~mm}$ 外張 & .19 & 1.10 & L & 1 & 12.3 & 20.9 & 超えず & $1 \mathrm{~s}$ & 66 & 81 & 85 & 8 & 13 & 178 \\
\hline $3-2$ & 断熱 & $60 \mathrm{~mm}$ & 2.13 & 02 & なし & 12.2 & 12.3 & 23.8 & 超えず & 1 & 48 & 5 & 82 & & 1 & 160 \\
\hline 3-3 & 工法 & $100 \mathrm{~mm}$ 外張 & 3.19 & 3.08 & なし & 12.3 & 12.5 & 28.5 & 超えず & 15 & 31 & 35 & 79 & 8 & 94 & 97 \\
\hline $2-3$ & 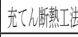 & $100 \mathrm{~mm}$ 充てん & 2.39 & 2.99 & なし & 11.7 & 20.8 & - & 54.7 & 17 & 63 & 78 & 10 & 11 & 18 & 245 \\
\hline 4-1 & 付加 & $25 \mathrm{~mm}$ 付加 & 3.13 & 3.64 & なし & 11.5 & 20.4 & 38.8 & 超えず & 1 & 10 & 23 & 44 & 7 & 85 & 94 \\
\hline $4-2$ & 断熱 & $60 \mathrm{~mm}$ 付加 & 4.11 & 4.57 & なし & 11.4 & 19.7 & 46.4 & 超えず & 14 & $\begin{array}{lll}7 & \\
\end{array}$ & 10 & 29 & o & 69 & 86 \\
\hline & & $100 \mathrm{~mm}$ & & 6 & & & & 56. & 㗉え & 26 & & & 15 & & 31 & \\
\hline
\end{tabular}

*GB 表面：せっこうボード（GB）の加熱面側表面＊*外張断熱材表面：外張断熱材の加熱面側表面＊***外張断熱材裏面 : 外張断熱材の非加熱面側表面

表 10 木柱最小断面の断面積残存率と断面二次モーメント、木柱の炭化速度（屋内加熱）

\begin{tabular}{|c|c|c|c|c|c|c|c|c|c|}
\hline \multirow{2}{*}{\multicolumn{2}{|c|}{$\begin{array}{l}\text { 断熱工法 } \\
\text { 試験体仕様 }\end{array}$}} & \multirow{2}{*}{\begin{tabular}{||c|c|c|} 
無断熱 \\
1-1.無断熱壁体
\end{tabular}} & \multicolumn{3}{|c|}{ 外張断熱工法 } & \multirow{2}{*}{ 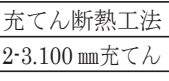 } & \multicolumn{3}{|c|}{ 付加断熱工法 } \\
\hline & & & $3-1.25 \mathrm{~mm}$ 外張 & $3-2.60 \mathrm{~mm}$ 外張 & 3-3.100 mm外張 & & 4-1.25 mm付加 & 4-2.60 mm付加 & 4-3.100 mm付加 \\
\hline 木柱断面写真 & 最小断面 & & & & & & & & \\
\hline 断面積残存率 & 最小断面 & $31.3 \%$ & $32.7 \%$ & $23.6 \%$ & $24.9 \%$ & $25.9 \%$ & $40.7 \%$ & $44.2 \%$ & $48.1 \%$ \\
\hline 断面二次モーメント(m $\left(\mathrm{mm}^{4}\right)$ & 最小断面 & $1.06 \times 10^{6}$ & $1.25 \times 10^{6}$ & $0.67 \times 10^{6}$ & $0.79 \times 10^{6}$ & $0.73 \times 10^{6}$ & $1.61 \times 10^{6}$ & $1.99 \times 10^{6}$ & $1.97 \times 10^{6}$ \\
\hline 断面二次モーメント残存率 & 最小断面 & $10.4 \%$ & $12.3 \%$ & $6.3 \%$ & $7.8 \%$ & $7.2 \%$ & $15.9 \%$ & $19.6 \%$ & $19.5 \%$ \\
\hline 柱角部·炭化速度(mm/分) & 温度測定位置 & 0.83 & 0.70 & 0.79 & 欠測 & 欠測 & 0.70 & 0.79 & 0.84 \\
\hline
\end{tabular}

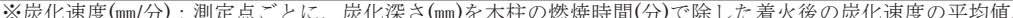

※屋内加熱では柱の損傷が柱裏面まで及び、柱側面での加熱条件が柱側面からの一面加熱でなくなったため、柱側面の炭化速度は求めないこととした。
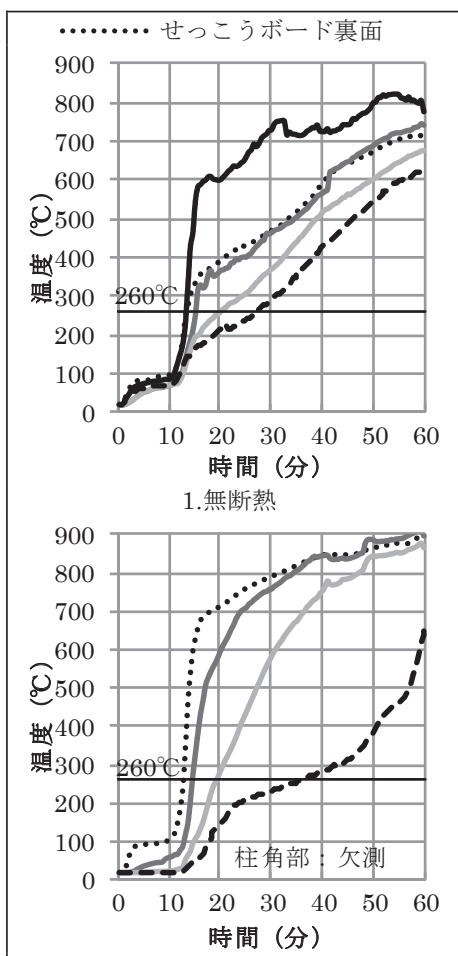

2-3.100 mm充て

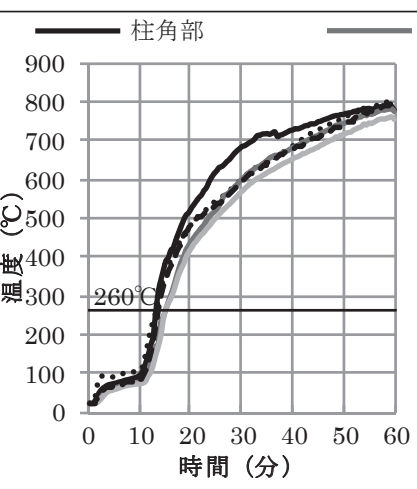

$3-1.25 \mathrm{~mm}$ 外張

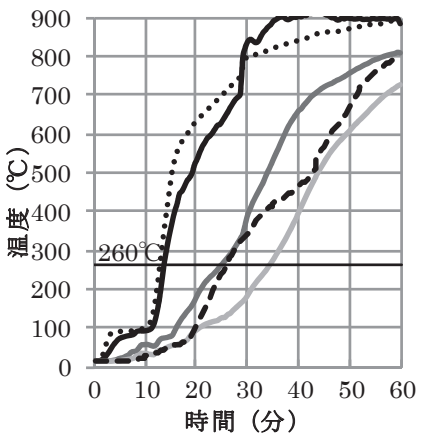

4-1.25 mm付加

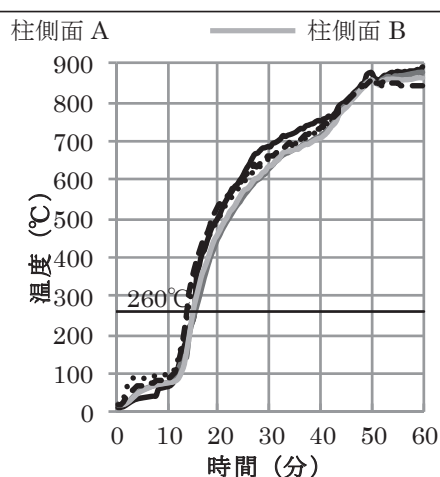

3-2.60 mm外張

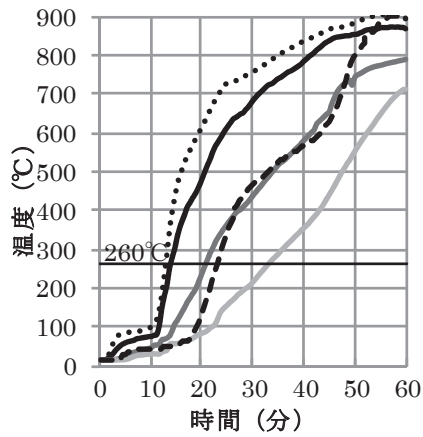

4-2.60 mm付加

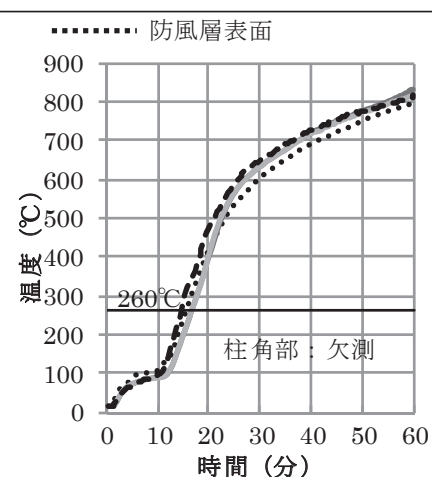

3-3.100 mm外張

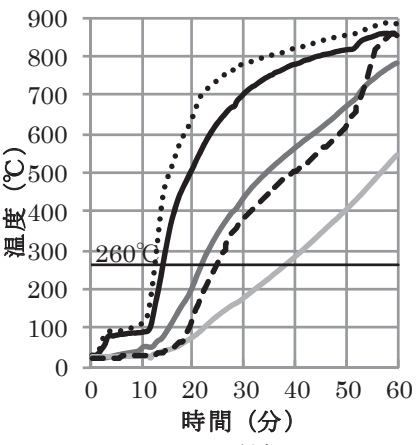

4-3.100 mm付片分

図 12 木柱側面部の平均温度推移（上段 : 外張断熱工法・屋内加熱、下段 : 付加断熱工法・屋内加熱) 
法と比較しても充てん断熱材による木柱の被覆効果は発揮され、付 加断熱工法の非損傷性は外張断熱工法より向上している。

付加断熱工法でも、内装側のせっこうボードにできた亀裂により、 火炎が壁体内に侵入したと考えられる。しかし付加断熱工法では、 木柱は加熱面となる柱正面はせっこうボード、それ以外の 3 面はす べて断熱材で覆われている。そのため充てん断熱工法に比べ、木柱 周辺の断熱材の通気抵抗が相対的に高くなり、木柱と断熱材の間の 隙間を通る火熱が少なくなった結果、充てん断熱材による被覆効果 が顕在化したと考えられる。また付加断熱材が厚くなるにつれ、木 柱の断面積残存率が若干向上している。付加断熱材が厚くなること で木柱周辺の断熱材の通気抵抗が増したためと考えられる。

以上より、付加断熱工法では、充てん断熱工法に比べ、木柱周辺 の断熱材の通気抵抗が相対的に高くなり、充てん断熱材による木柱 の被覆効果が発揮される。非損傷性は充てん断熱工法、外張断熱工 法に比べ高く、付加断熱材が厚くなるにつれ向上する傾向がある。

\section{5. まとめ}

木造断熱壁体において、断熱工法ごとに壁体の防耐火性能と断熱 材の厚さや位置との関係を明らかにすることを目的に、ロックウー ル断熱材を用いた木造壁体を対象に、内外装材が脱落しない条件で 小型試験体による加熱試験を行った。

充てん断熱工法、外張断熱工法、付加断熱工法いずれにおいても、 今回試験を行った壁体はすべて、屋外加熱、屋内加熱に対し、60 分 の遮炎性を有しており、遮熱性は断熱材厚さが増すことで向上する ことが確認された。しかしながら非損傷性は、断熱材によって必ず しも性能が向上するとは言えず、低下寸る場合が見られた。以下、 本研究で得られた非損傷性に関する知見を断熱工法ごとに記す。

\section{5-1. 充てん断熱工法}

・屋外加熱では充てん断熱材の位置、厚さにより、断熱材と木柱と の位置関係、壁体内の温度分布が変化し、木柱が受ける損傷状況 が異なる。軸間に断熱材を充てんすることで無断熱壁体に比べ非 損傷性が低下寸る場合がある。

・屋内加熱では内装材のせっこうボードの厚さ、張り方を工夫しな い限り、加熱開始後短時間に、目地を通じて、火炎が壁体内に侵 入する可能性が高く、充てん断熱材による木柱の被覆効果が期待 できない場合が多いと考えられる。充てん断熱材の幅を柱間より 広くし、断熱材を木柱側面に密着させるよう施工にすることで、 木柱の被覆効果が発現でき、非損傷性が向上する。

\section{$5-2$. 外張断熱工法}

・屋外加熱では外張断熱材が厚いほど非損傷性は向上寸る。

・屋内加熱では外張断熱材によって、非損傷性は無断熱壁体よりも 不利側に作用するが、外張断熱材厚さ $60 \mathrm{~mm}$ 以上では、外張断熱 材厚さが非損傷性に与える影響は小さい。

\section{$5-3$. 付加断熱工法}

・屋外加熱では付加断熱材が厚いほど非損傷性は向上する。一方、 外張断熱工法に比べると、柱角部での着火時間、炭化速度は早く なる。外張（付加）断熱材厚さが十分でないと、外張断熱工法に 断熱材を充てんして付加断熱工法とした際に、非損傷性が低下寸 る場合がある。
・屋内加熱では充てん断熱工法に比べ、木柱周辺の断熱材の通気抵 抗が高くなり、充てん断熱材による木柱の被覆効果が発揮される。 そのため非損傷性は充てん断熱工法、外張断熱工法に比べ高くな る。また付加断熱材が厚くなるにつれ、若干であるが、非損傷性 が向上する傾向がある。

今回の検討で、軸間に断熱材を充てんすることは、遮熱性の向上 には繋がるものの、非損傷性の低下を招く場合があること、また、 その影響は断熱工法によって異なるが、断熱材の充てん方法によっ て非損傷性の低下を抑制できる見通しがあることなどが明らかにな った。小型試験であるため、非損傷性への影響については、断熱工 法において長期荷重を支持する木柱の断面性能への影響の把握に留 まったが、この結果をもとに力学的検討を加え、実大試験による検 証と合わせながら、より精緻な検討を行っていきたい。

\section{謝辞}

本研究は、北方建築総合研究所およびロックウール工業会との共 同研究「新たな防火性能を付与した木造高断熱壁体の開発」の一環 として行われた。宮崎孝司専務理事をはじめロックウール工業会の 皆様方には、多大なるご助言、ご協力を賜りました。また試験実施 にあたっては、北方建築総合研究所の野村広幸氏および小川貢氏に 多大なるご協力を賜りました。ここに深く感謝の意を表します。

\section{関連する既往発表論文}

・糸毛治・鈴木大隆：ロックウール断熱材を用いた木造外張断熱工法の遮熱 性能に関する考察, 日本建築学会大会学術講演梗概集（東北）, $A-2$ 分冊 pp277-278, 2009. 9

\section{参考文献}

1）財団法人建築環境省エネルギー機構 : 住宅の省エネルギー基準の解説第 3 版第 7 刷，pp187-192，2010.12

2）地方独立行政法人北海道立総合研究機構 : 防而火性能試験 - 評価業務方法 書, 2010.6

3）安井昇 - 長谷見雄二 - 秋月通孝 - 馬屋原敦 - 大西卓 - 上島基英 - 畑俊充 . 木村忠紀、田村佳英・村上博 : 木造土壁の各部仕様が防耐火性能に及ぼす 影響 日本建築学会環境系論文集, 第 567 号, pp7-13, 2003.5

4）安井昇・清水真理子 - 長谷見雄二 ・ 村上雅英 -上島基英 - 木村忠紀 $\cdot$ 北後 明彦・田村佳英・吉田正友・山本幸一：柱圧縮実験による木造土壁の火炎 加熱時の非損傷性予測と木造土壁外壁の防火設計, 日本建築学会環境系論 文集，第 574 号，pp1-6，2003. 12

5）清水真理子・長谷見雄二・村上雅英・安井昇 : 木造真壁の耐火性能予測, 日 本建築学会構造系論文集, 第 611 号, pp165-170, 2007.1

（2012年 1 月10日原稿受理，2012年 3 月 2 日採用決定） 